Revision Article

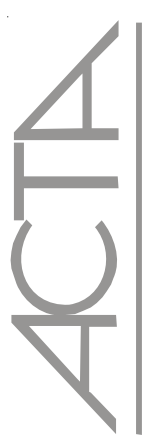

\title{
Steam sterilization of previously-assembled laparoscopic instruments
}

\author{
Esterilização pelo vapor dos instrumentos laparoscópicos previamente montados \\ Esterilización por vapor de los instrumentos laparoscópicos previamente armados
}

\author{
Tamara Carolina de Camargo ${ }^{1}$, Caroline Dal Pian Alarcon Rocha ${ }^{1}$, Kazuko \\ Uchikawa Graziano ${ }^{2}$
}

\begin{abstract}
Video-laparoscopy represents one of the greatest surgical advances in the recent past. Reprocessable laparoscopic instruments are complex devices that, if completely disassembled for sterilization, would cause problems for the surgical teams at the moment of their use in the surgery. The method of choice for the sterilization of this equipment is saturated steam under pressure. The goal of this review was to describe the state-of-the-art in the search for safe results in autoclaving the previously-assembled reprocessable laparoscopic instruments, since they are difficult to assemble at the moment of surgery. The PUBMED database was consulted, using controlled and free keywords, as well as their combinations, without time or language restrictions. The study investigating the exact issue of this research found contamination in both assembled $(1 / 24)$ and disassembled (1/30) instruments, demonstrating equivalent risks. In view of the results and considering the lack of studies, a new experimental laboratory study is recommended, using a contamination challenge.
\end{abstract}

Keywords: Sterilization; Heat transference; Surgical instruments; Laparoscopy; Operating room nursing.

\section{RESUMO}

A vídeo-laparoscopia representa um dos maiores avanços na área da cirurgia nos últimos tempos. Os instrumentos laparoscópicos reprocessáveis são artigos complexos, que se esterilizados totalmente desmontados trazem transtornos às equipes cirúrgicas no momento da sua utilização no campo operatório. $\mathrm{O}$ método de escolha para a esterilização desses instrumentos é o vapor saturado sob pressão. O objetivo dessa revisão foi descrever o estado da arte em busca dos resultados da segurança na autoclavação do instrumental laparoscópico reprocessável, previamente montado, tendo em vista as dificuldades de montagem deles no momento da cirurgia. Foi consultada a base de dados PUBMED, usando vocábulos controlados, livres e a combinação deles, sem restrição de tempo e idioma. Foram localizados apenas dois artigos que permitiram conclusões favoráveis para a prática de autoclavar os instrumentos laparoscópicos previamente montados. O estudo que investigou exatamente a questão da pesquisa encontrou contaminação após a esterilização, tanto em instrumentos montados $(1 / 24)$ como nos desmontados $(1 / 30)$, demonstrando equivalência do risco. Frente aos resultados, e considerando a escassez de trabalhos sobre o assunto, recomenda-se um novo estudo experimental laboratorial randomizado utilizando contaminação desafio.

Descritores: Esterilização, Transferência de calor; Instrumentos Cirúrgicos, Laparoscopia; Enfermagem de Centro Cirúrgico

\section{RESUMEN}

El video-laparoscopía representa uno de los mayores avances en el área de la cirugía en los últimos tiempos. Los instrumentos laparoscópicos reprocesables son artículos complejos, que si son esterilizados totalmente desarmados ocasionan trastornos a los equipos quirúrgicos en el momento de su utilización en el campo operatorio. El método de elección para la esterilización de esos instrumentos es el vapor saturado bajo presión. El objetivo de esta revisión fue describir el estado del arte en búsqueda de los resultados de la seguridad en el autoclavado del instrumental laparoscópico reprocesable, previamente armado, teniendo presente las dificultades de su montaje en el momento de la cirugía. Se consultó la base de datos PUBMED, usando vocablos controlados, libres y la combinación de ambos, sin restricción de tiempo e idioma. Fueron localizados apenas dos artículos que permitieron conclusiones favorables para la práctica del autoclado de los instrumentos laparoscópicos previamente armados. En el estudio que investigó exactamente el asunto de la investigación encontró contaminación después de la esterilización, tanto en instrumentos armados $(1 / 24)$ como en los desarmados $(1 / 30)$, demostrando equivalencia de riesgo. Frente a los resultados, y considerando la escasez de trabajos al respecto, se recomienda un nuevo estudio experimental de laboratorio randomizado utilizando contaminación desafío. Descriptores: Esterilización, Transferencia del calor; Instrumentos quirúrgicos; Laparoscopia; Enfermería de quirófano

${ }^{1}$ Master in Nursing in Adult Healthcare at Escola de Enfermagem da Universidade de São Paulo - USP - São Paulo (SP), Brazil.

${ }^{2}$ Professor at the Surgical-Medical Nursing Department of Escola de Enfermagem da Universidade de São Paulo - USP - São Paulo (SP), Brazil. 


\section{INTRODUCTION}

Video-laparoscopy represents one of the greatest surgical advances in the recent past. Initially a target of heavy criticism and distrust, it has gradually become more accepted because of its obvious advantages, especially the fast recovery of the patient, shorter hospital stays, faster social and professional reintegration and better aesthetic results ${ }^{(1)}$.

Currently, two types of laparoscopic instruments are available: reprocessable and single-use. Single-use instruments, a priori, should not be reprocessed, according to the manufacturer's guidelines. Those marketed as reprocessable can be completely disassembled and steam-autoclaved under pressure. They are the object of this literature review.

Like any new technology, laparoscopic video-surgery has entailed new responsibilities and challenges for the nursing team working in surgical services, especially at the Center of Materials and Sterilization, responsible for processing these instruments. The instruments used in video-laparoscopic surgeries are complex devices, composed of several parts which, if disassembled completely for sterilization, would cause problems for the surgical teams at the moment of their use in the surgery. There is also a risk of incorrect assembly, compromising their performance. When sterilizing the aforementioned previously-assembled instrument, the setback mentioned would be avoided, and the possibility of misplacing parts of the laparoscopic instruments could be circumvented.

The method of choice for sterilization of laparoscopic instruments is saturated steam under pressure ${ }^{(2-6)}$, since they are thermo-resistant.

Perkins $^{(3)}$ states that steam is the sterilization principle of the autoclaves, and the mechanism of microbial destruction is related not only to direct contact of steam with the material, but also to latent heat, causing the microbial proteins to thermocoagulate.

Latent heat can be understood as heat received by a given material during the water's change of physical state, with the same temperature being maintained. During the sterilization process, saturated steam under pressure in contact with the material's cold surface placed in the internal chamber of the autoclave undergoes condensation (water transformation, from gaseous state to liquid state), which releases latent heat, humidifying and heating the material simultaneously. Therefore, this latent heat, by thermocoagulating the microbial proteins, will kill the microorganisms, and sterilization happens due to the exchange of heat between the environment and the object to be sterilized. The condensation of one gram of steam releases 524 calories $^{(5)}$.

Despite theoretical references on latent heat in steam sterilization, which would theoretically justify the sterilization of previously-assembled laparoscopic instruments, the Association of Registered Operating Nurses of the United States of America (USA), considered a worldwide reference in the Surgical Center complex area, does not recommend assembly of the material before sterilization ${ }^{(7)}$. Therefore, the guiding question of this literature review was defined as follows: In literature, is there evidence of the safety of previously-assembled, reprocessable laparoscopic instrument sterilization by autoclaves with saturated steam under pressure, based on the principle of latent heat?

Thus, the goal of this review was to describe the stateof-the-art of the basic studies* seeking results about safety in autoclaving previously-assembled reprocessable laparoscopic instruments due to assembly difficulties at the moment of surgery.

\section{METHODS}

The bibliographic research was performed in the PUBMED electronic database in January 2007, with no restrictions to period or language. This database is under the responsibility of the US National Library of Medicine. The Boolean operator AND was used with the following keywords: sterilization AND surgical instruments AND laparoscopy AND laparoscopic AND steam sterilization AND assembled. The three first keywords used are controlled by the Medical Subject Headings (MeSH), and the last three are free keywords.

This search strategy, combining indexed keywords and free keywords, without restrictions of research type, date, language and other characteristics that could limit findings in the search sources, guarantees that all relevant studies were accessed.

\section{RESULTS}

The literature search produced: 8 articles for surgical instruments $[\mathrm{MeSH}]$ AND assembled, 32 articles for sterilization $[\mathrm{MeSH}]$ AND surgical instruments [MeSH] AND steam sterilization, 25 articles for sterilization [MeSH] AND assembled, 1 article for sterilization [MeSH] AND surgical instruments [MeSH] AND steam sterilization AND laparoscopic AND assembled, and no articles for sterilization [MeSH] AND surgical instruments [MeSH] AND laparoscopy [MeSH] AND steam sterilization AND assembled.

The titles and abstracts of these publications were

\footnotetext{
* Basic studies: these are considered as research that tests interventions or control/correlate and/or compares effects of variables in a given phenomenon, including control groups or not, under laboratory or field conditions, independently of temporality. They are also called primary studies ${ }^{(8)}$.
} 
analyzed. The article found with the combination of the terms [MeSH] AND surgical instruments [MeSH] AND steam sterilization AND laparoscopic AND assembled contained, in its "Related Links" section, an article $e^{(9)}$ reporting on a basic study. Moreover, in this latter study's "Related Links", another study was found ${ }^{(10)}$, both related with the specific issue of the present review. The other articles were discarded, because they addressed aspects of the sterilization of healthcare material but did not look at the topic safety of assembled or disassembled sterilized laparoscopy instruments, object of study of the present review.

The first article ${ }^{(9)}$ is from Dallas (USA) and was published in 1991. It is a laboratory study with the hypothesis that the previously-assembled laparoscopy instrument has the same sterility safety when compared to the disassembled model. The second article ${ }^{(10)}$ reports on a publication from Mississippi (USA), in 1995, where the authors also performed a laboratory study to determine the efficiency of steam-sterilizing laparoscopic instruments with blocked lumens, with a high concentration of organic matter (meat - hamburger mass) and intentionally inoculated microorganisms. This study, although not exactly characterizing research with assembled laparoscopic instruments, was included in this review because it considered the blocking of the lumens as a challenge for the direct non-penetration of the steam, and the heat was conveyed through the material according to the principle of latent heat, which is the theoretical reference of the present review.

In the first study, the authors ${ }^{(9)}$ used, as samples, four different types of laparoscopic instruments: a $10 \mathrm{~mm}$ trocar, a $5 \mathrm{~mm}$ trocar, a pair of Grasper tweezers and a pair of bipolar tweezers. These materials were contaminated with three types of vegetative-form bacteria: (Serratia marcescens, Bacillus subtilis and Bacillus stearothermophilus) and with two bacterial spores: one known to be resistant to ethylene oxide (de Bacillus subtilis spores), and the other resistant to steam sterilization (Bacillus stearothermophilus spores). After the preparation of the bacterial substances, these were inoculated in 10 distinct locations of the instruments tested ( 3 places in the $10 \mathrm{~mm}$ trocar, 5 places in the $5 \mathrm{~mm}$ trocar, one in the Grasper tweezers and one in the bipolar tweezers). A previouslysterilized swab was used for this procedure. The places of inoculation were those considered critical for the retention of organic matter and, consequently, difficult to clean. The authors submitted the materials tested to two different protocols in order to verify the efficiency of sterilization, which are described next:

In Protocol 1, the instruments were disassembled and contaminated in different places by swabbing with the microbial suspensions described above. Afterwards, without previous washing, the instruments were assembled, packaged and submitted to sterilization by ethylene oxide - ETO (1 hour 45 minutes of sterilization and 20 hours of airing) and by steam $\left(4\right.$ minutes at $\left.132^{\circ} \mathrm{C}\right)$.

In Protocol 2, the materials were submitted to the same contamination challenge and, afterwards, manually washed. Next, the sample was divided into three groups: In the first group, the instruments were previously assembled and submitted to steam sterilization; in the second group, the instruments were submitted to the same sterilization process, but disassembled; and, in the third group, the instruments were stored disassembled, in environmental conditions, serving as the positive control group.

After sterilization, samples were collected for culture in each previously-contaminated place, using sterilized swabs moist with trypticase soy broth (TSB). These were placed in a tube with $3.5 \mathrm{ml}$ of the same culture medium. These tubes were incubated for seven days at the specified temperatures for the microorganisms tested (Serratia marcescens and Bacillus subtilis at 35oC; Bacillus stearothermopbilus at $560 \mathrm{oC})$. Three replications of each instrument were tested.

This study ${ }^{(9)}$ obtained the following results: With the application of Protocol 1 (sterilization without prior cleaning, assembled): All vegetative bacteria died after sterilization, by both ETO and steam. The spores survived, with $30 \%$ of the sample with positive growth (9/30) when sterilized by ETO and $13 \%$ positive growth $(4 / 30)$ when sterilized by steam. The application of Protocol 2 found positive results for the Bacillus stearothermophilus spores, for both assembled and disassembled instruments, with $1 / 30$ positive cultures in disassembled instruments and $1 / 24$ positive cultures in the assembled instruments.

The other study ${ }^{(10)}$ described two experiments and used scenarios beyond the worst possible clinical situation.

In the first experiment, a reprocessable trocar with a $12 \mathrm{~mm}$-diameter lumen was used. The cannula was filled with meat (hamburger mass), contaminated with a $0.5 \mathrm{ml}$ suspension containing Proteus mirabilis, Enterococcus feacalis, Staphylococcus aureus, S. epidermidis, Actinomyces pyrogenes, Cândida albicans and Escherichia coli, at the concentration of $1.8 \times 10^{9}$ colony forming units per milliliter. After this procedure, the material was autoclaved with 10 -minute conventional cycles of exposure and 3-minute flash cycles of exposure at $132^{\circ} \mathrm{C}$ temperature and cooled for two minutes. Next, the samples of the meat mass were placed in blood agar plates and incubated in a clinical laboratory for 72 hours. The article does not describe the microbiological techniques of the sterilization tests in detail. Twenty-one experiments were performed with the conventional cycle, with each microorganism being evaluated three times, and 42 experiments were performed in the flash cycles, with each microorganism 
being evaluated six times. In this first experiment, all microorganisms were eliminated.

The study authors ${ }^{(10)}$ attributed the efficiency of steam sterilization in these conditions to the fundamental laws of Physics:

..."the contact of steam with the cold objects converted steam into liquid, and the formidable transference of heat or energy (five times the amount of energy that would be released to cool water from $100^{\circ}$ to $0^{\circ} \mathrm{C}$ ). The energy transfer, referred as latent heat from vaporization, was quickly conveyed by the conductivity of the metal cannula to its internal part, and effectively coagulated the vegetative proteins of the microorganisms, inducing their death. The high atmospheric pressure of the steam autoclaves increased the amount of energy (heat) transferred to the laparoscopic instruments during condensation. Within the worst experimental scenario, there was enough thermal energy was conducted, despite the metal cannulas being closed by covering the lumens with hamburger mass. It killed the contaminant pathogenic organisms within 3 minutes. The key for sterilization is the contact of the microorganism with the heat, not necessarily direct contact with steam".

In the second experiment, described in the same article, the authors evaluated the efficiency of sterilization by steam, using, as a challenge, a unit of the commercially available biological marker Bacillus stearothermophilus, standardized to monitor the efficiency of the autoclave cycles. This contaminant was introduced in the lumen of the reprocessable trocar, along with the hamburger meat, promoting the "closing" of its orifice to avoid the free circulation of steam through the lumen. Ten samples were submitted to sterilization at different time intervals $(3,4$, 5, 6, 7 and 10 minutes), totaling 60 tests. Simultaneously, the same tests were performed with Bacillus stearothermophilus, but without adding hamburger meat into the lumens, with five repetitions, comprising the negative control. After the process of sterilization, the markers were incubated at $55^{\circ} \mathrm{C}$ for 48 hours, and watched daily for microbial recovery. Of the spores contained in the "closed" trocars, $100 \%$ survived to 3 and 4 minutes of steam exposure; $60 \%$ survived to 5 minutes, $10 \%$ to 6 minutes and $100 \%$ died in 7 and 10 minutes of steam exposure. All the spores inserted in the "open" trocars were destroyed with only 3 minutes of steam exposure ${ }^{(10)}$.

\section{DISCUSSION}

In the search for scientific evidence in literature that support the autoclaving of reprocessable instruments used in previously-assembled laparoscopic instruments, only one study was found that encouraged the possibility of this practice. Although the research results ${ }^{(9)}$ did not destroy the bacterial spores completely, this outcome was verified in both the disassembled instrument group
(Control group: 1/30) and the assembled group (Experimental group: 1/24), which allows for the conclusion that risks are equivalent, in favor of the possibility of sterilizing the previously-assembled laparoscopic instruments in steam under pressure. The result of this research showed the growth of bacterial spores as the imposed challenge, representing a much worse scenario than clinical practice.

Laparoscopic instruments are normally contaminated with microorganisms in vegetative state (easy to eliminate), not in the form of spores. Also, the microbial density is low, as shown in studies by Ribeiro ${ }^{(11)}$, in which the critical material of complex conformation (angiography catheter), after cleaning, contained Gram-positive cocci and bacilli (vegetative microorganisms) between $10^{2-3}$ colony forming units per material. Likewise, ChanMyers ${ }^{(12)}$ retrieved between 0 and $10^{3}$ colony forming units per instrument after cleaning from the laparoscopies, also composed of vegetative microorganisms.

The clinical essay by Voyles et al. ${ }^{(10)}$ clearly reinforces the power of latent heat in the destruction of bacterial spores. This study showed that steam does not necessarily need to have contact with all surfaces of the laparoscopic instrument to promote destruction of the spore microorganisms tested, which is in favor of safety in autoclaving assembled laparoscopic instruments. It is true that the presence of organic matter made it difficult to destroy the bacterial spores tested, demanding longer exposure for its total elimination, but success was obtained.

The possibility of sterilizing previously-assembled laparoscopic instruments by means of steam under pressure undoubtedly eases work for many hospitals.

\section{FINAL CONSIDERATIONS}

Although the study by Marshburn, Rutala, Wannamaker and Hulka ${ }^{(9)}$ allows for favorable conclusions for the practice of processing assembled laparoscopic instruments by means of steam saturation under pressure - due to the equivalence of the risk demonstrated between sterilization while assembled or disassembled considering the lack of basic studies about the safety of this practice, a new experimental randomized laboratory essay study is recommended, using the contamination challenge. Even acknowledging that the outcome occurrence of infection of the surgical site - is the most sensitive and specific marker to support or refute the practice discussed herein, ethical issues prevent the performance of clinical studies in patients about this problem. Therefore, as a research design for future investigation, it is proposed that the results of cultures of assembled laparoscopic instruments (experimental group) and disassembled laparoscopic instruments (control group), previously contaminated with a Geobacillus 
stearothermophilus suspension in spore form (a microorganism that is indicated as biological monitor in the routine control of the efficiency of sterilization cycles by saturated steam under pressure), add sterilized

\section{REFERENCES}

1. Nasi A, Domene CE, Santo MA, Pinotti HW. Equipamentos e instrumental. In: Pinotti HW, Domene CE. Cirurgia vídeo laparoscópica. São Paulo: Robe; 1993. p. 73-87.

2. Spaulding EH. Chemical disinfection of medical and surgical materials. In: Lawrence CA, Block SS. Disinfection, sterilization and preservation. Philadelphia: Lea \& Febiger; 1968. p. 517-31

3. Perkins JJ. Minimum standards for sterilization. In: Perkins $\mathrm{JJ}$. Principles and methods of sterilization in health sciences. 2a ed. Springfield: Charles C Thomas; 1983. p. 154-67.

4. Nakamura MHY, Padoveze MC, Quelhas MC, Kocssis E. Esterilização por vapor saturado sob pressão. In: Padoveze MC, Del Monte MCC, coordenadores. Esterilização de artigos em unidades de saúde. 2a ed. São Paulo: Associação Paulista de Estudos e Controle de Infecção Hospitalar; 2003. p. 82-97.

5. Graziano KU. Processo de limpeza, desinfecção e esterilização de artigos odonto-médico hospitalares e cuidados com ambiente em centro cirúrgico. In: Lacerda RA. Controle de infecção em centro cirúrgico: fatos, mitos e controvérsias. São Paulo: Atheneu; 2003. p. 163-95.

6. Pinter MG, Gabrielloni MC. Validação de embalagens de algodão duplo e papel grau cirúrgico: relato de experiência. Acta Paul Enferm. 2000; 13(N Esp Pt 2): 94-5. defibrinated lamb blood to increase the challenge and bring it closer to clinical practice. The sample size should be significant in order to offer statistical test power of approximately $99.9 \%$

7. Association PeriOperative Registred Nurse. Sterilizations in perioperative practice settings. In: Standards, recommended practices, and guidelines. Unites States: Association periOperative Registred Nurse; 2006. p. 629-44.

8. Denser CPAC, Lacerda RA. Reprocessamento e reutilização de material odonto-médico-hospitalar de uso único: a busca de evidências pela revisão sistemática de literatura científica. Acta Paul Enferm. 2006; 19(3): 316-22.

9. Marshburn PB, Rutala WA, Wannamaker NS, Hulka JF. Gas and steam sterilization of assembled versus disassembled laparoscopic equipment. Microbiologic studies. J Reprod Med. 1991; 36(7):483-7.

10. Voyles CR, Sanders DL, Simons JE, McVey EA, Wilson WB. Steam sterilization of laparoscopic instruments. Surg Laparosc Endosc. 1995; 5(2):139-41.

11. Ribeiro SMCP. Reprocessamento de cateteres de angiografia cardiovascular após uso clínico e contaminados artificialmente: avaliação da eficácia da limpeza e da esterilização [Tese]. São Paulo: Escola de Enfermagem da Universidade de São Paulo; 2006.

12. Chan-Myers H, McAlister D, Antonoplos P. Natural bioburden levels detected on rigid lumened medical devices before and after cleaning. Am J Infect Control. 1997; 25(6):471-6. 